\title{
Prevalence and Density of Digenetic Trematode Metacercariae in Clams and Oysters from Western Coastal Regions of the Republic of Korea
}

\author{
Woon-Mok Sohn",*, Byoung-Kuk Na', Shin-Hyeong $\mathrm{Cho}^{2}$, Won-Ja Lee ${ }^{2}$ \\ ${ }^{1}$ Department of Parasitology and Tropical Medicine, and Institute of Health Sciences, Gyeongsang National University School of Medicine, Jinju \\ 52727, Korea; 'Division of Malaria and Parasitic Diseases, National Research Institute of Health, Centers for Disease Control and Prevention, \\ Osong 28159, Korea
}

\begin{abstract}
A survey was performed to know the recent infection status of digenetic trematode metacercariae in clams and oysters from 4 sites in western coastal regions of the Republic of Korea (=Korea). Four species of clams (Mactra veneriformis, Ruditapes philippinarum, Cyclina sinensis, and Saxidomus purpuratus) were collected from Taean-gun, Chungcheongnam-do (Province), Buan-gun (County) and Gochang-gun, Jeollabuk-do, and oysters, Crassostrea gigas, from Shinan-gun, Jeollanam-do were transferred to our laboratory on ice and examined by the artificial digestion method. The metacercariae of Himasthla alincia were detected in 3 species of clams, $M$. veneriformis, R. philippinarum, and C. sinensis from the 3 surveyed areas. The positive rate and the mean density per clam infected were $98.9 \%$ (30.8 metacercariae) in M. veneriformis, $60.0 \%$ (5.0) in R. philippinarum, and $96.0 \%$ (28.4) in C. sinensis. The positive rate (mean density) of Acanthoparyphium tyosenense metacercariae in $M$. veneriformis was $50.0 \%$ (2.1) from Taean-gun and $70.0 \%$ (2.8) from Gochang-gun. The metacercariae of Parvatrema spp. were detected in $M$. veneriformis and $R$. philippinarum from Taean-gun and Gochang-gun; the positive rate (mean density) was $63.3 \%(4,123)$ and $50.0 \%(19)$ in $M$. veneriformis, and $6.7 \%(126)$ and $100 \%$ (238) in R. philippinarum from the 2 regions, respectively. The metacercariae of Gymnophalloides seoi were detected in all 30 oysters from Shinan-gun, and their average density per oyster was 646 . From the above results, it has been confirmed that more than 3 species of metacercariae are prevalent in clams from the western coastal regions, and G. seoi metacercariae are still prevalent in oysters from Shinan-gun, Jeollanam-do, Korea
\end{abstract}

Key words: Himasthla alincia, Acanthoparyphium tyosenense, Parvatrema sp., clam, oyster

\section{INTRDUCTION}

Digenetic trematodes are a relatively large trematode group comprising of more than 2,500 nominal genera. It commonly has 3 hosts ( 2 intermediate and 1 definitive) in the life cycle. Various kind of animals, i.e., mollusc, fish, amphibian, reptilian, and arthropod, act as the second intermediate hosts, which retained the infective larvae, i.e., metacercariae. Especially, it has been known that some species of digenetic trematode metacercariae are detected in molluscan hosts, the clam and oyster [1-3]. In the Republic of Korea (=Korea), some species of gymnophallid metacercariae were detected from the inter-

\footnotetext{
- Received 1 May 2017, revised 19 May 2017, accepted 31 May 2017.

*Corresponding author (wmsohn@gnu.ac.kr)

(c) 2017, Korean Society for Parasitology and Tropical Medicine

This is an Open Access article distributed under the terms of the Creative Commons Attribution Non-Commercial License (http://creativecommons.org/licenses/by-nc/4.0) which permits unrestricted non-commercial use, distribution, and reproduction in any medium, provided the original work is properly cited.
}

tidal clams and oysters [4-11]. Some species of echinostomatid metacercariae were also found in the brackish water gastropods [12-16].

Yu et al. [4] first detected Parvatrema duboisi (syn. P. timondavidi) metacercariae from Manila clams, Ruditapes philippinarum, and Sohn et al. [10] recorded Parvatrema chaii n. sp. (Digenea: Gymnophallidae), which were recovered from mice experimentally infected with the metacercariae collected from the surf-clam Mactra veneriformis. Lee et al. [5] first found that the oyster, Crassostrea gigas, is the second intermediate host (the source of human infection) of Gymnophalloides seoi. Kim and Yun [9] surveyed on larval trematodes in 3 species of bivalves, Corbicula japonica, Sinonovacula constricta, and R. philippinarum, from some sites in the Yellow Sea. Chai et al. [11] reported a new gymnophallid trematode, Meiogymnophallus sinonovaculae n. sp., recovered from the small intestines of mice infected with metacercariae from the razor clam, S. constricta. On the other hand, Kim and Chun [12] detected Himasthla kusasigi 
metacercariae in the clam, Meretrix lusori. Kim [13] also found 2 species of echinostomatid metacerceriae, H. kusasigi and Acanthoparyphium tyosenense, from 3 species of intertidal clams, i.e., M. veneriformis, Cyclina sinensis, and Solen strictus. After then, Chai et al. [14] discovered human infections with A. tyosenense, and they also investigated the metacercarial infections of this fluke in 5 species of bivalves, i.e., M. veneriformis, Solen grandis, Meretrix petechialis, C. sinensis, and Scapharca broughtonii, and a marine snail, Neverita bicolor, to survey on the sources of human infections. Han and Chai [15] reported for the first time that $M$. veneriformis act as the second intermediate host of Acanthoparyphium marilae.

The infection status of Parvatrema sp. metacercariae was investigated in R. philippinarum collected from southern coastal areas of Korea [6]. Lee et al. [7] performed a nationwide survey of naturally produced oysters to know the infection status with G. seoi metacercariae. Most of the previous studies were performed to identify the specific trematode species from the limited host animals and areas [4-16]. However, the metacercarial infection status of intertidal bivalves collected from the western coastal regions has not been widely and systematically examined. Therefore, we investigated the infection status of 5 species of bivalves from 4 local sites in the western coast of Korea with the trematode metacercariae.

\section{MATERIALS AND METHODS}

\section{Subjected samples by surveyed areas}

In July 2013, total 4 species of clams (Mactra veneriformis, Ruditapes philippinarum, Cyclina sinensis and Saxidomus purpuratus) were collected from 3 western coastal regions (Fig. 1), i.e., Taean-gun (latitude: 36.4710; longitude: 126.3408) in Chungcheongnam-do, Buan-gun $(35.0727 ; 126.0734)$ and Gochang-gun $(35.5009 ; 126.4907)$ in Jeollabuk-do, Korea. A total of $90 \mathrm{M}$. veneriformis were collected in all 3 regions, Taean-gun $(\mathrm{n}=30)$, Buan-gun $(\mathrm{n}=20)$, and Gochang-gun $(\mathrm{n}=40)$. Two species of clams, $R$. philippinarum $(\mathrm{n}=25)$ and $C$. sinensis $(\mathrm{n}=25)$, were also collected with the same number in 2 regions, Taean-gun $(\mathrm{n}=15)$ and Gochang-gun $(\mathrm{n}=10)$, respectively. In Buan-gun, $10 \mathrm{~S}$. purpuratus were collected. To investigate the recent infection status of G. seoi metacercariae, oysters, Crassostrea gigas, were collected in July 2013 from a tidal flat of Aphae-myeon (Township) in Shinan-gun (34.0839; 126. 3508), Jeollanam-do, a well-known endemic area of this fluke [16].

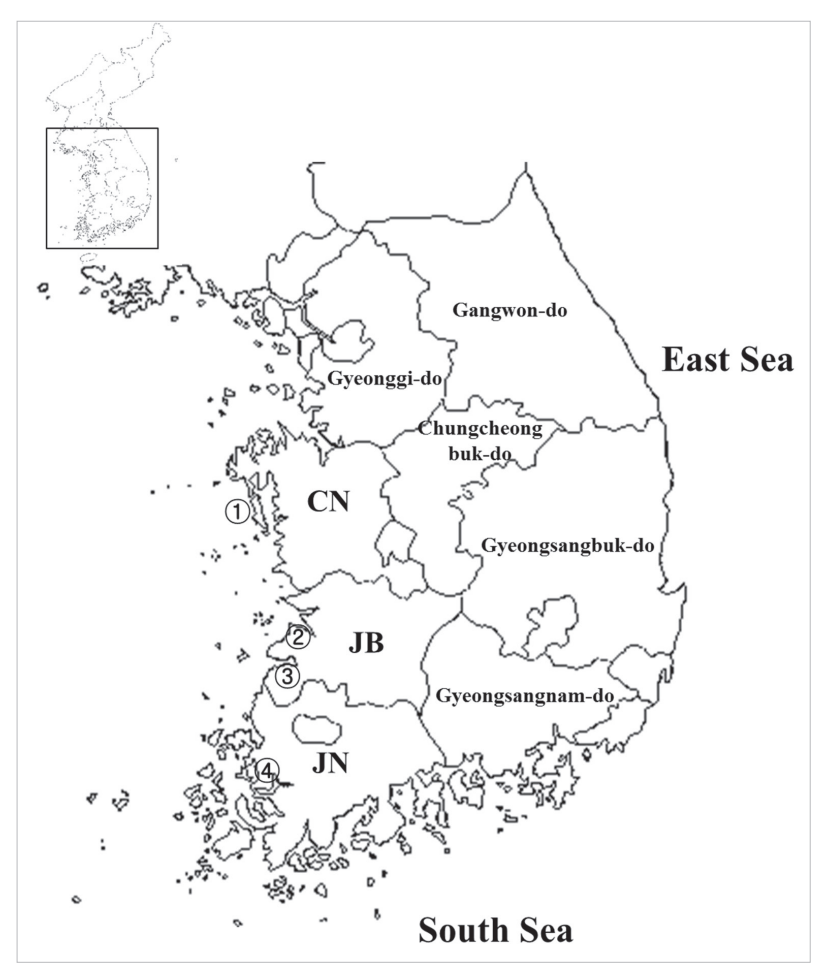

Fig. 1. Surveyed areas in (1) Taean-gun (latitude: 36.4710; longitude: 126.3408), Chungcheongnam-do (CN); (2) Buan-gun (35.0727; 126.0734) and (3) Gochang-gun (35.5009; 126.4907), Jeollabuk-do (JB); (4) Shinan-gun (34.0839; 126.3508), Jeollanam-do (JN), Korea.

\section{Examination of the metacercarial infection status in clams and oysters}

All collected clams and oysters were transferred on ice to the laboratory of the Department of Parasitology and Tropical Medicine, Gyeongsang National University School of Medicine, Jinju, Korea. After species identification, the bivalves were individually opened with a knife. Each opened sample (the animal part and 2 shells) was mixed with artificial gastric juice, and the mixture was incubated at $36^{\circ} \mathrm{C}$ for $1-2 \mathrm{hr}$ with occasional stirring (at 15-20 min interval). The digested material was filtered through a $1 \times 1 \mathrm{~mm}$ mesh, and washed with $0.85 \%$ saline until the supernatant became clear. The sediment was carefully examined under a stereomicroscope. Each species of metacercariae were separately collected by the general feature, and they were counted to get hold of the infection rate (\%) and density (no. of metacercariae per clam infected) by clam species.

\section{Observation of metacercariae and experimental infection to animals}

Some representative metacercariae collected with a stereo- 
microscope were morphologically observed under a light microscope equipped with a micrometer (OSM-4, Olympus, Tokyo, Japan) to identify their exact species. Especially, the metacercariae of Parvatrema spp. detected in M. veneriformis from Taean-gun were fixed with $10 \%$ formalin under a cover slip, and then stained with Semichon's acetocarmine to observe their morphological characteristics. The collected metacercariae were orally infected with a gavage needle to chicks and hamster to obtain adult worms. Two species of echinostomes, Himasthla alincia and Acanthoparyphium tyosenense, were recovered in the small intestines of chicks at 2 weeks after infection. Many specimens of Parvatrema spp. were also recovered in the small intestines of hamsters at day 5 after the infection. The experimental animals, hamsters and chicks, were treated according to the guidelines of Institutional Animal Care and Use Committee (IACUC) in Gyeongsang National University. The recovered worms were fixed with $10 \%$ formalin under a cover glass pressure, and then stained with Semichon's acetocarmine to observe their morphological characteristics.

\section{RESULTS}

\section{Infection status of $M$. veneriformis with trematode metacercariae}

More than 3 species of metacercariae, i.e., Himasthla alincia, A. tyosenense, and Parvatrema spp., were detected in M. veneriformis. The metacercariae of $H$. alincia were found in $98.9 \%$ clams, and their mean density was 30.8 per clam infected. The metacercariae of A. tyosenense were detected in $47.8 \%$ clams, and their mean density was 2.5 per clam infected. Parvatrema spp. metacercariae were found in $43.3 \%$ clams, and their mean density was 2,018 per clam infected. The metacercarial infection status by the surveyed area is designated in detail in Table 1.
Infection status of $R$. philippinarum with trematode metacercariae

More than 2 species of metacercariae, i.e., H. alincia and Parvatrema spp., were detected from $R$. philippinarum. The metacercariae of $H$. alincia were found in $80.0 \%$ and $30.0 \%$ clams from Taean-gun and Gochang-gun, and their mean densities were 5.8 and 1.7 per clam infected, respectively. Parvatrema spp. metacercariae were detected in $6.7 \%$ and $100 \%$ clams from Taean-gun and Gochang-gun, and their mean densities were 126 and 238 per clam infected, respectively (Table 2).

\section{Infection status of $C$. sinensis and $S$. purpuratus with trematode metacercariae}

Only 1 species, $H$. alincia, was detected from $C$. sinensis clams. The metacercariae were found in $93.3 \%$ and $100 \%$ clams from Taean-gun and Gochang-gun, and their mean densities were 5.5 and 60.5 per clam infected, respectively (Table 3). No metacercariae were found in $10 \mathrm{~S}$. purpuratus collected in Buan-gun, Jeollabuk-do.

\section{Infection status of oysters with $G$. seoi metacercariae}

The metacercariae of $G$. seoi were detected in all 30 oysters

Table 2. Infection status in esturine clams, Ruditapes philippinarum, from 2 western coastal regions of Korea with trematode metacercariae

\begin{tabular}{|c|c|c|c|c|}
\hline \multirow{2}{*}{$\begin{array}{l}\text { Locality and } \\
\text { trematode species }\end{array}$} & \multirow{2}{*}{$\begin{array}{c}\text { No. (\%) of } \\
\text { clams infected }\end{array}$} & \multicolumn{3}{|c|}{ No. of metacercariae detectec } \\
\hline & & Total & Range & Average \\
\hline \multicolumn{5}{|l|}{ Taean-gun $(n=15)$} \\
\hline Himasthla alincia & $12(80.0)$ & 70 & $1-11$ & 5.8 \\
\hline Parvatrema sp. & $1(6.7)$ & 126 & - & 126 \\
\hline \multicolumn{5}{|l|}{ Gochang-gun $(n=10)$} \\
\hline Himasthla alincia & $3(30.0)$ & 5 & $1-2$ & 1.7 \\
\hline Parvatrema sp. & $10(100)$ & 2,377 & $80-615$ & 238 \\
\hline
\end{tabular}

Table 1. Infection status of clams, Mactra veneriformis, from 3 western coastal regions of Korea with trematode metacercariae

\begin{tabular}{|c|c|c|c|c|}
\hline \multirow{2}{*}{ Locality and trematode species } & \multirow{2}{*}{ No. (\%) of clams infected } & \multicolumn{3}{|c|}{ No. of metacercariae detected } \\
\hline & & Total & Range & Average \\
\hline \multicolumn{5}{|l|}{ Taean-gun $(n=30)$} \\
\hline Himasthla alincia & $30(100)$ & 1,352 & $4-120$ & 45.1 \\
\hline Acanthoparyphium tyosenense & $15(50.0)$ & 31 & $1-7$ & 2.1 \\
\hline Parvatrema sp. & $19(63.3)$ & 78,331 & $7-18,900$ & 4,123 \\
\hline \multicolumn{5}{|l|}{ Buan-gun $(n=20)$} \\
\hline Himasthla alincia & $20(100)$ & 480 & $2-70$ & 24.0 \\
\hline \multicolumn{5}{|l|}{ Gochang-gun $(n=40)$} \\
\hline Himasthla alincia & $39(97.5)$ & 912 & $6-174$ & 23.4 \\
\hline Acanthoparyphium tyosenense & $28(70.0)$ & 77 & $1-8$ & 2.8 \\
\hline Parvatrema sp. & $20(50.0)$ & 382 & $4-43$ & 19.1 \\
\hline
\end{tabular}


$(100 \%)$ collected from Aphae-myeon in Shinan-gun, Jeollanam-do, and their density was 646 per oyster in average. The metacercarial density by the weight group of oysters is shown in detail in Table 4.

\section{Morphology of $H$. alincia metacercariae and adults}

Metacercariae (Fig. 2A): Cyst oval or round, 240-257 (249) x232-250 (242) in size with 5-9 (7) thick cyst wall, had a head collar with 31 collar spines that included 4 lateral end-group spines on each side, and 2 excretory ducts filled with numerous fine granules.

Adults (Fig. 2B): Body markedly elongate, maximum width at the level of the anterior testis. Head crown distinct, bearing 31 collar spines arrange in a single uninterrupted row, with 4 end group spines on each side of ventral corners (Fig. 2C). Oral

Table 3. Infection status of esturine clams, Cyclina sinensis, from 2 western coastal regions of Korea of trematode metacercariae

\begin{tabular}{lcccc}
\hline \multirow{2}{*}{$\begin{array}{c}\text { Locality and } \\
\text { trematode species }\end{array}$} & $\begin{array}{c}\text { No. (\%) of } \\
\text { clams infected }\end{array}$ & \multicolumn{2}{c}{ No. of metacercariae detected } \\
\cline { 4 - 6 } & Total & Range & Average \\
\hline $\begin{array}{c}\text { Taean-gun }(\mathrm{n}=15) \\
\text { Himasthla alincia }\end{array}$ & $14(93.3)$ & 77 & $1-17$ & 5.5 \\
$\begin{array}{c}\text { Gochang-gun }(\mathrm{n}=10) \\
\text { Himasthla alincia }\end{array}$ & $10(100)$ & 605 & $10-21$ & 360.5 \\
\hline
\end{tabular}

sucker small, subterminal. Prepharynx very short. Pharynx subglobular. Esophagus short. Ceca bifurcating near the anterior margin of the ventral sucker, terminating blindly near the posterior extremity. Ventral sucker slightly elliptical. Sucker ratio (oral sucker:ventral sucker) approximately 1:2.93. Cirrus sac elongate, dorsal to ventral sucker, containing seminal vesicle, prostate gland cells, and a cirrus. Ovary spherical, on the median or slightly dextral. Mehlis' gland located between the ovary and the anterior margin of the anterior testis. Two testes oval to elliptical, tandem, intercecal, near the posterior end of the body. Vitellaria follicular, distributing laterally from anterior $1 / 3$ of the body to near the posterior end. Uterus with eggs intercecal, from the Mehlis' gland to the anterior $2 / 3$ of the body. Eggs operculate, golden yellow, 93-108 (100) by 55-63 (60). Dimensions of each organ are revealed in detail in Table 5.

Table 4. Infection status of Gymnophalloides seoi metacercariae in oysters from Shinan-gun, Jeollanam-do

\begin{tabular}{lrrr}
\hline \multirow{2}{*}{$\begin{array}{l}\text { Weight of oysters } \\
\text { examined }\end{array}$} & \multicolumn{3}{c}{ No. of metacercariae detected } \\
\cline { 2 - 4 } & \multicolumn{1}{c}{ Total } & \multicolumn{1}{c}{ Range } & Average \\
\hline Below $30 \mathrm{~g}(\mathrm{n}=12)$ & 4,347 & $70-1,083$ & 362 \\
$31-40 \mathrm{~g}(\mathrm{n}=9)$ & 4,394 & $126-2,001$ & 488 \\
Over $41 \mathrm{~g}(\mathrm{n}=9)$ & 10,636 & $27-4,704$ & 1,181 \\
Total $(\mathrm{n}=30)$ & 19,377 & $27-4,704$ & 646 \\
\hline
\end{tabular}

Table 5. Comparison of the dimensions of Himasthla alincia adults with those of previous studies

\begin{tabular}{lccc}
\hline Organs & $\begin{array}{c}\text { Present study (2017) } \\
\text { Range (average) }\end{array}$ & $\begin{array}{c}\text { Han et al. [15] } \\
\text { Range (average) }\end{array}$ & $\begin{array}{c}\text { Kim and Chun [11] } \\
\text { Range }\end{array}$ \\
\hline Body length (BL) & $5,625-8,125(6,893)$ & $3,100-6,380(4,140)$ & $4,800-7,500$ \\
Body width (BW) & $475-675(535)$ & $320-510(430)$ & $220-240$ \\
Ratio of BL/BW & $12.88: 1$ & $19.63: 1$ & - \\
Head collar & $300-380(336)$ & $230-325(248)$ & - \\
Oral sucker (OS) & $100-125(104)$ & $65-90(75)$ & $68-120$ \\
& $\times 100-130(114)$ & $\times 65-90(77)$ & $\times 70-120$ \\
Pharynx & $100-130(117)$ & $83-113(94)$ & 80 \\
& $\times 80-115(96)$ & $\times 63-108(84)$ & 50 \\
Esophagus & $150-210(178)$ & $100-200(149)$ & $250-295$ \\
Ventral sucker (VS) & $290-340(312)$ & $180-320(225)$ & $630-680$ \\
& $\times 305-350(326)$ & $\times 200-290(242)$ & $\times 610-680$ \\
Ratio of OSNS & $1: 2.93$ & $1: 3.07$ & - \\
Ovary & $75-165(136)$ & $83-125(98)$ & $160-175$ \\
& $\times 80-240(158)$ & $\times 95-200(118)$ & in diameter \\
Anterior testis & $330-640(503)$ & $250-500(344)$ & $420-460$ \\
& $\times 160-350(245)$ & $\times 160-280(214)$ & $\times 245-320$ \\
Posterior testis & $395-740(534)$ & $280-550(350)$ & $460-520$ \\
Eggs & $\times 165-375(233)$ & $\times 110-290(206)$ & $\times 270-320$ \\
& $99-108(100)$ & $108-113(109)$ & $92-95$ \\
\hline
\end{tabular}

${ }^{\text {TT}}$ Total 10 worms recovered in the intestine of chicks at day 14 after infection.

${ }^{\mathrm{b}}$ Ten worms ( 15 day-old) from an experimental chick.

${ }^{\circ}$ Ten H. kusasigi worms (25 day-old) from an experimental herring gull, Larus crassirostris. 


\section{Morphology of Acanthoparyphium tyosenense metacercariae and adults}

Metacercariae (Fig. 3A): Cyst oval to round, 350-385 (377) in diameter, with thin cyst wall, a coiled larva and extensively distributed excretory granules. Two suckers, oral and ventral sucker, plainly visible. Head collar reniform, with 23 collar spines in a single row, without ventral corner spines.

Adults (Fig. 3B): Body elongate, medium, maximum width in acetabula level. Head crown distinct, bearing about 23 collar spines in a single row, without end group ones (Fig. 3C). Oral sucker small, subterminal. Prepharynx absent. Pharynx subglobular. Esophagus short. Ventral sucker large, well developed. Sucker ratio (oral sucker:ventral sucker) approximately 1:2.93. Cirrus sac well developed and contained saccular seminal vesicle. Ovary spherical, on the dextro-median line of the body. Two testes spherical, tandem. Vitellaria follicular, distributing laterally from the level of anterior testis to posterior end. Eggs operculate, golden yellow. Dimensions of each organ are shown in detail in Table 6.

\section{Morphology of Parvatrema spp. metacercariae collected in M. veneriformis from Taean-gun}

The metacercariae of Parvatrema spp. collected in M. veneriformis from Taean-gun, Chungcheongnam-do were morphologically divided into 3 types (Fig. 4). Generally, their body very tiny and ovoid, with fine tegumental spines, maximum width at acetabular level. Oral sucker large and well developed, with lateral projections on each side. Prepharynx absent. Pharynx round and muscular. Ceca inflated oval sacs, extended to the level of the ventral sucker. Ventral sucker round, posterior to midline. Sucker ratio was 2.49:1 in average. Ovary oval to round and slightly smaller than testes, dextroanterior to the right testis. Testes round, nearly symmetrical, posterolateral to the ventral sucker. Genital pore, a wide slit-like opening, in the middle between the oral and ventral suckers. Excretory bladder V-shaped with 2 arms extending to the oral sucker level. Dimensions of each organ by the morphological type are designated in detail in Table 7.
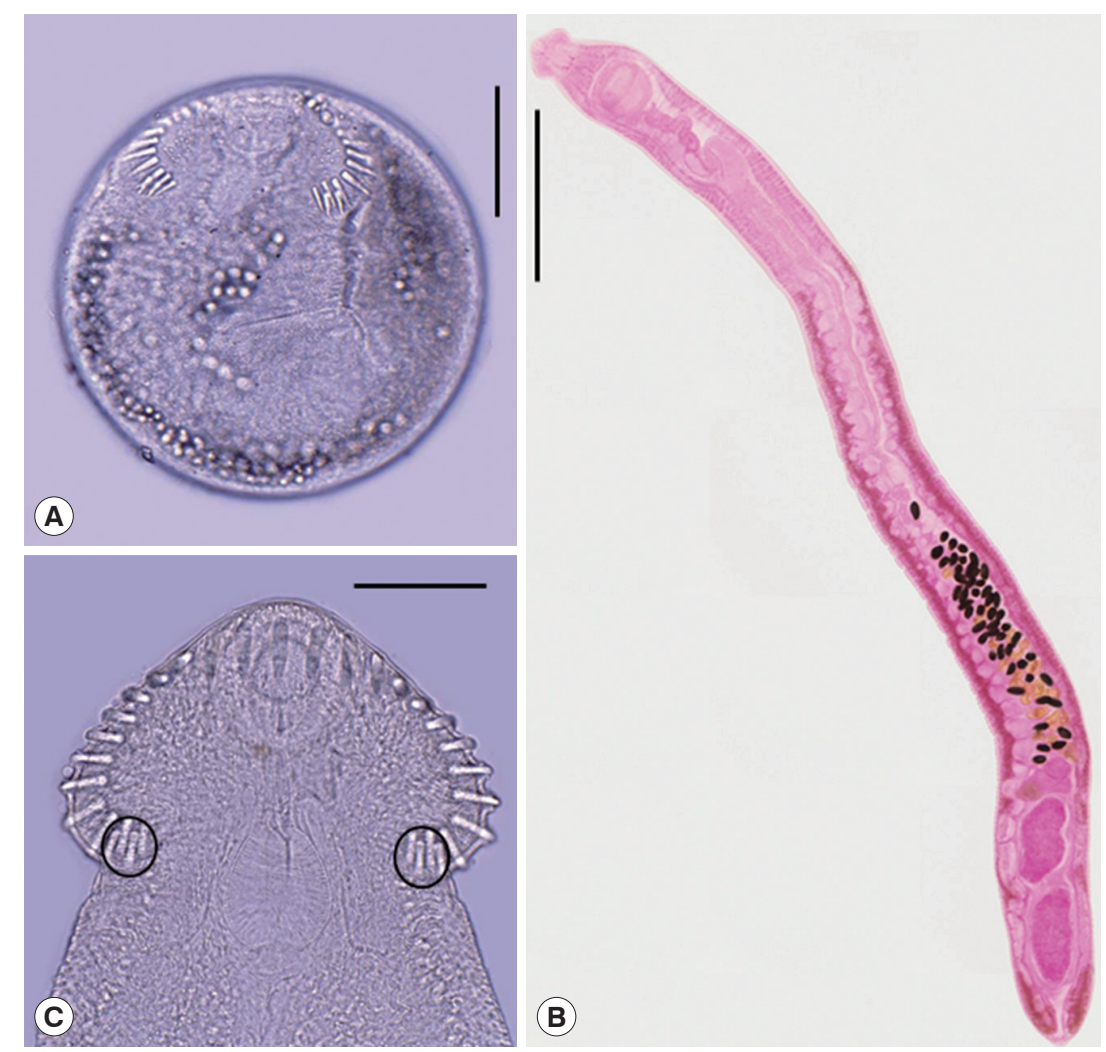

Fig. 2. Himasthla alincia. (A) Metacercaria detected in a Mactra veneriformis clam from Taean-gun, Chungcheongnam-do (Scale bar $=75$ $\mu \mathrm{m})$. (B) Adult (Semichon's acetocarmine stained) recovered from the small intestine of a chick experimentally infected with metacercariae (Scale bar =1,000 $\mu \mathrm{m})$. (C) The head collar of an adult with 31 collar spines that included 4 lateral end-group ones (encircled) on each side (Scale bar $=100 \mu \mathrm{m})$. 
Table 6. Comparison of the dimensions of Acanthoparyphium tyosenense adults with those of previous studies

\begin{tabular}{|c|c|c|c|}
\hline Organs & $\begin{array}{l}\text { Present study (2017) } \\
\text { Range (average) }\end{array}$ & $\begin{array}{l}\text { Chai et al. [13] } \\
\text { Range (average) }\end{array}$ & $\begin{array}{c}\text { Kim }[12]^{c} \\
\text { Range }\end{array}$ \\
\hline Body length (BL) & $2,275-2,700(2,450)$ & $2,480-3,130(2,830)$ & $2,900-3,500$ \\
\hline Body width (BW) & $700-775$ (725) & $520-730(630)$ & $600-680$ \\
\hline Ratio of BL/BW & $3.38: 1$ & 4.49:1 & - \\
\hline Head collar & $305-320$ (312) & $250-300$ (270) & $260-290$ \\
\hline Oral sucker (OS) & $\begin{array}{c}90-105(97) \\
\times 125-135(127)\end{array}$ & $\begin{array}{l}90-110(100) \\
\text { in diameterin }\end{array}$ & $\begin{array}{l}100 \\
\text { diameter }\end{array}$ \\
\hline Pharynx & $\begin{array}{r}95-100(99) \\
\times 55-65(59)\end{array}$ & $\begin{array}{r}80-100(90) \\
\times 60-90(70)\end{array}$ & $\begin{array}{r}87-95 \\
\times 37-40\end{array}$ \\
\hline Esophagus & $200-240(216)$ & $170-280(220)$ & $250-420$ \\
\hline Ventral sucker (VS) & $\begin{array}{r}290-340(307) \\
\times 330-365(349)\end{array}$ & $\begin{array}{l}240-320(290) \\
\text { in diameterx }\end{array}$ & $\begin{array}{l}270-300 \\
360-380\end{array}$ \\
\hline Ratio of OS/NS & $1: 2.93$ & $1: 2.90$ & - \\
\hline Ovary & $\begin{array}{r}100-125(117) \\
\times 135-170(155)\end{array}$ & $\begin{array}{r}110-140(120) \\
\times 130-180(150)\end{array}$ & $\begin{array}{r}90-100 \\
\times 120-160\end{array}$ \\
\hline Anterior testis & $\begin{array}{r}215-325(278) \\
\times 350-435(396)\end{array}$ & $\begin{array}{r}260-330(290) \\
\times 310-390(350)\end{array}$ & $\begin{array}{r}240-370 \\
\times 400-460\end{array}$ \\
\hline Posterior testis & $\begin{array}{r}275-375(330) \\
\times 350-415(369)\end{array}$ & $\begin{array}{r}320-370(340) \\
\times 290-380(340)\end{array}$ & $\begin{array}{r}230-340 \\
\times 320-450\end{array}$ \\
\hline Eggs & $\begin{array}{r}93-98(95) \\
\times 54-59(56)\end{array}$ & $\begin{array}{l}105-111(108) \\
\times 55-63(59)\end{array}$ & $\begin{array}{l}80-110 \\
\times 60-65\end{array}$ \\
\hline
\end{tabular}

${ }^{a}$ Total 10 worms recovered in the intestine of chicks at day 14 after infection.

${ }^{\mathrm{b} T e n}$ worms ( 15 day-old) from an experimental chick.

'Ten worms (15 day-old) from an experimental herring gull, Larus crassirostris.
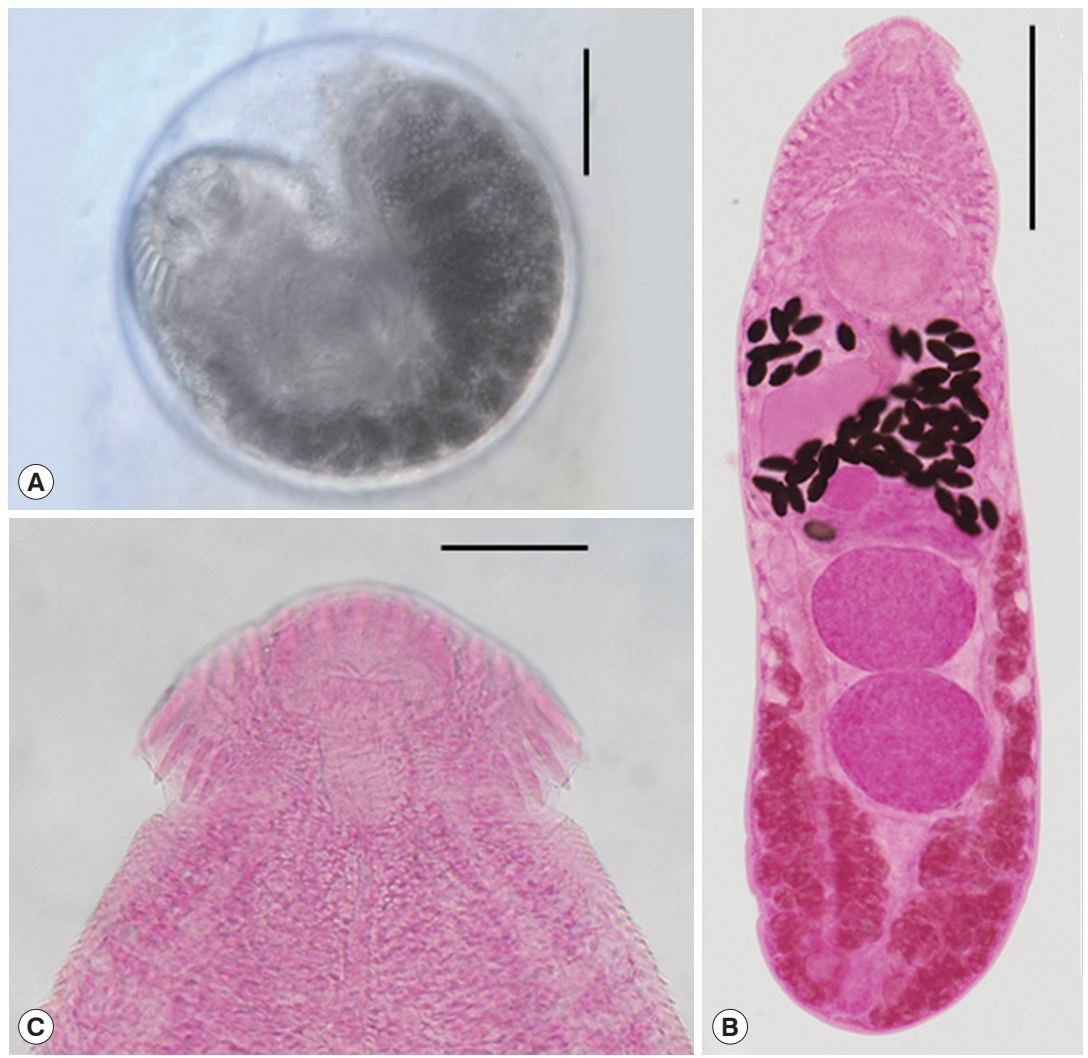

Fig. 3. Acanthoparyphium tyosenense. (A) Metacercaria detected in a M. veneriformis clam from Gochang-gun, Jeollabuk-do (Scale bar $=100 \mu \mathrm{m})$. (B) Adult (Semichon's acetocarmine stained) recovered from the small intestine of a chick experimentally infected with metacercariae (Scale bar=500 $\mu \mathrm{m})$. (C) The head collar of an adult with 23 collar spines (Scale bar =100 $\mu \mathrm{m})$. 
Table 7. Dimensions ${ }^{a}$ of Parvatrema sp. metacercariae collected in esturine clams, Mactra veneriformis, from Taean-gun

\begin{tabular}{|c|c|c|c|}
\hline Organs & $\begin{array}{c}\text { Type A } \\
\text { Range (average) }\end{array}$ & $\begin{array}{c}\text { Type B } \\
\text { Range (average) }\end{array}$ & $\begin{array}{c}\text { Type C } \\
\text { Range (average) }\end{array}$ \\
\hline Body length (BL) & $225-288(250)$ & $195-230(211)$ & 178-223 (199) \\
\hline Body width (BW) & $130-150(142)$ & $128-148(138)$ & $140-150(147)$ \\
\hline Ratio of BL/BW & $1.76: 1$ & $1.53: 1$ & $1.35: 1$ \\
\hline Oral sucker (OS) & $\begin{array}{r}58-65(61) \\
\times 65-75(69)\end{array}$ & $\begin{array}{r}55-65(61) \\
\times 60-70(66)\end{array}$ & $\begin{array}{r}50-65(57) \\
\times 63-73(67)\end{array}$ \\
\hline Ratio of OS/BL & $1: 3.85$ & $1: 3.32$ & $1: 3.21$ \\
\hline Pharynx & $\begin{array}{r}23-30(27) \\
\times 18-25(22)\end{array}$ & $\begin{array}{r}18-23(20) \\
\times 15-23(18)\end{array}$ & $\begin{array}{r}18-33(25) \\
\times 18-33(23)\end{array}$ \\
\hline Ventral sucker (VS) & $\begin{array}{r}23-28(25) \\
\times 28-30(28)\end{array}$ & $\begin{array}{r}23-25(24) \\
\times 25-30(28)\end{array}$ & $\begin{array}{r}20-28(24) \\
\times 25-30(27)\end{array}$ \\
\hline Ratio of OS/NS & $2.60: 1$ & $2.44: 1$ & $2.43: 1$ \\
\hline Ovary & $\begin{array}{r}18-30(23) \\
\times 13-23(18)\end{array}$ & $\begin{array}{r}18-28(23) \\
\times 13-23(18)\end{array}$ & $\begin{array}{r}18-25(23) \\
\times 13-23(18)\end{array}$ \\
\hline Right testis & $\begin{array}{r}25-40(31) \\
\times 15-30(24)\end{array}$ & $\begin{array}{r}23-30(28) \\
\times 20-25(22)\end{array}$ & $\begin{array}{r}23-33(27) \\
\times 18-25(21)\end{array}$ \\
\hline Left testis & $\begin{array}{r}25-33(29) \\
\times 20-28(23)\end{array}$ & $\begin{array}{r}25-30(28) \\
\times 18-25(22)\end{array}$ & $\begin{array}{r}23-30(26) \\
\times 18-25(22)\end{array}$ \\
\hline Vitellaria & $\begin{array}{r}18-30(24) \\
\times 15-25(17)\end{array}$ & $\begin{array}{r}15-20(17) \\
\times 10-15(14)\end{array}$ & $\begin{array}{r}18-23(19) \\
\times 10-15(14)\end{array}$ \\
\hline
\end{tabular}

${ }^{a}$ Ten metacercariae each were measured (unit $\left.=\mu \mathrm{m}\right)$.
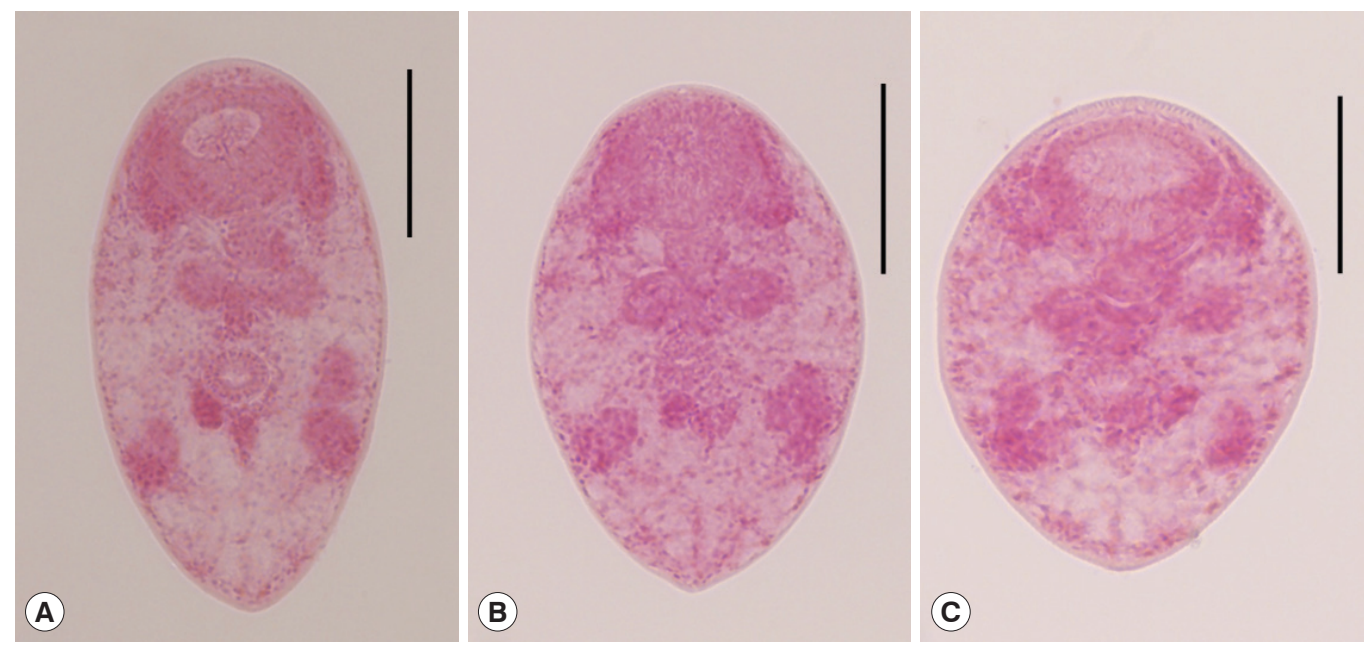

Fig. 4. The metacercariae of Parvatrema sp. (Semichon's acetocarmine stained) detected in M. veneriformis clams from Taean-gun, Chungcheongnam-do. (A) Type A is morphologically similar to $P$. chaii metacercariae. (B) Type B is apparently similar to $P$. duboisi metacercariae, although their body size is much smaller than those of $P$. duboisi. (C) Type $\mathrm{C}$ is more or less plump in shape (Scale bars $=75 \mu \mathrm{m})$.

\section{DISCUSSION}

By the present study, it has been clarified that more than 3 species of trematode metacercariae, i.e., H. alincia, A. tyosenense, and Parvatrema spp., are prevalent in 3 species of clams (M. veneriformis, R. philippinarum, and C. sinensis) from 3 west coastal regions, i.e., Taean-gun, Buan-gun, and Gochang-gun. G. seoi metacercariae were still prevalent in oysters from Shinan-gun, Jeollanam-do. Among more than 4 species of trema- todes detected in this study, at least 2 (A. tyosenense and G. seoi) are human-infecting flukes [17-20]. Chai et al. [14] first reported 10 human cases of A. tyosenense infections, with 1-107 worm burdens, in an endemic area of heterophyid flukes in Buan-gun, Jeollabuk-do, Korea [21]. Lee et al. [17] described Gymnophalloides seoi n. sp. (Digenea: Gymnophallidae), which was recovered from a Korean woman suffering from acute pancreatitis and gastrointestinal troubles. This human case was the first human infection by a gymnophallid [17]. After 
then, the village where the patient resided was found to be a high endemic area of G. seoi; additional endemic areas were also found thereafter [18-22].

Chai et al. [14] investigated 5 species of bivalves (M. veneriformis, S. grandis, M. petechialis, C. sinensis, and S. broughtonii) and 1 species of marine snail ( $N$. bicolor) to know the infection sources of A. tyosenense. They detected A. tyosenense metacercariae in 3 molluscan species, M. veneriformis, S. grandis, and N. bicolor, purchased from the endemic area (Buan-gun, Jeollabuk-do). The prevalence of $A$. tyosenense metacercariae was $100 \%$ in 3 molluscan species, and the density was 134 metacercariae in M. veneriformis, 133 in S. grandis, and 23 in N. bicolor. Kim [13] also surveyed the metacercarial infection status in 3 species of clams, M. veneriformis, C. sinensis, and Solon strictus, collected from Naechodo (Island) in the estuary of Geumgang (River); total 208 A. tyosenense metacercariae were detected in 63 out of $100 \mathrm{~S}$. strictus examined. In the present study, A. tyosenense metacercariae were found only in M. veneriformis collected from Taean-gun and Gochang-gun, and their prevalences (mean density/clam infected) were 50.0\% (2.1) in Taean-gun and 70.0\% (2.8) in Gochang-gun. Unlike Chai et al. [14], A. tyosenense metacercariae were not detected in 20 M. veneriformis collected in Buan-gun in this study. The endemicity of $A$. tyosenense metacercariae in this study was more or less similar with that of Kim [13]; however, it was very low when compared with that of Chai et al. [14].

Since Lee et al. [5] first reported that the oyster is the second intermediate host of G. seoi, some epidemiological studies on the infection status of oysters with metacercariae were done in coastal areas of Korea $[5,7,8]$. Especially, the oysters naturally produced in Aphae-myeon, Shinan-gun, Jeollanam-do [18] were most frequently investigated. Lee et al. [5] detected 2-4,792 (av. 610) metacercariae of G. seoi in 50 oysters from Aphae-myeon. Later, Lee et al. [7] also reported av. 786 metacercariae in 20 oysters from Aphae-myeon. Sohn et al. [8] investigated the monthly infection status with G. seoi metacercariae in 20 oysters each time collected in the same site of Aphae-myeon; total 248 (88.6\%) oysters were infected with av. 1,339 metacercariae. In the present study, G. seoi metacercariae were detected in all 30 (100\%) oysters from Aphae-myeon, with the mean density of 646 per oyster. Therefore, the mean metacercarial density in this study was similar with that of Lee et al. [5], slightly lower than that of Lee et al. [7], and much lower than that of Sohn et al. [8]. On the other hand, Lee et al. [5] mentioned that the metacercarial density had no relationship with the size of oysters. How- ever, in Sohn et al. [8] and the present study, the metacercarial density was proportional to the increase of the oyster weight.

Among the 27-nominated species of the genus Himasthla, 3 species, namely, H. alincia, H. kusasigi, and H. megacotyle, were reported in Korea $[12,16,23]$. The morphological characteristics of $H$. alincia are highly similar to those of $H$. kusasigi, especially in that they commonly have 31 collar spines, whereas $H$. megacotyle bears 28 collar spines. However, $H$. kusasigi is distinguished from $\mathrm{H}$. alincia in that it has a more slender body and its vitelline follicles extended more anteriorly toward the end of the cirrus sac (Table 7) [24,25]. In this respect, our specimens were identified as $\mathrm{H}$. alincia (Fig. 1). The metacercariae of this fluke were detected in 5 species of bivalves (M. veneriformis, S. grandis, C. sinensis, M. petechialis, and R. philippinarum) from a coastal area in Buan-gun, Jeollabuk-do [16]. In the present study, they were detected in 3 species of bivalves (M. veneriformis, C. sinensis, and R. philippinarum) from 3 western coastal areas (Taean, Buan, and Gochang) of Korea. The metacercarial density was much higher in Han et al. [16] than in this study.

In the genus Acanthoparyphium, 14 species, namely, A. phoenicopteri, A. spinulosum, A. ochthodromi, A. marilae, A. squatarolae, A. charadrii, A. kurogamo, A. melanittae, A. spinulosum suzugamo, A. tyosenense, A. paracharadrii, A. loborchis, A. haematopium, and A. macracanthum, have been listed so far [26-28]. Of these, A. tyosenense was originally described with worms from the small intestine of the duck Melanitta fusca stejnegeri and M. nigra americana caught in Korea [24]. This fluke was treated as a synonym of A. kurogamo by Skrjabin [29] and Chen [27]. However, A. tyosenense is a valid species, and it differs from A. kurogamo by its body shape and position of the acetabulum and testes $[14,24]$. Although another species, A. marilae, has been reported in Korea [15], the morphological characteristics of our specimens are well corresponded with those of A. tyosenense (Fig. 2). Comparative dimensions are designated in Table 6.

Until now, 3 species in the genus Parvatrema (Digenea: Gymnophallidae), i.e., P. duboisi (=P. timondavidi), P. chaii, and $P$. homoeotecnum, have been reported in Korea $[4,10,23]$. Among them, P. homoeotecnum was described only with adults, which were detected in the intestines of a migratory bird, the Mongolian plover (Charadrius mongolus), from the coastal area of Gunsan-si (City), Jeollabuk-do [23]. The remaining 2 species were described not only based on the adults but also on the metacercarial stage. Yu et al. [4] first detected P. duboisi metacercariae from intertidal clams, $R$. philippinarum, and de- 
scribed with adults recovered from experimental mice. Sohn et al. [6] subsequently surveyed on the infection status with Parvatrema sp. metacercariae in $R$. philippinarum from 13 areas in southern coastal areas of Korea. After that time, Sohn et al. [10] erected a new species, P. chaii n. sp., with adults recovered from mice experimentally infected with metacercariae from surf-clams, M. veneriformis, which were collected from a tidal flat located in Seocheon-gun, Chungcheongnam-do, Korea. In the present study, we found Parvatrema spp. metacercariae in 2 species of clams, $R$. philippinarum and M. veneriformis. Especially, in M. veneriformis clams collected from Taean-gun, lots of Parvatrema spp. metacercariae were detected and they were morphologically divided into 3 types (Fig. 3). The metacercariae Type A were morphologically similar to $P$. chaii metacercariae although their body shape (ratio of $\mathrm{BL} / \mathrm{BW}=1.76: 1$ ) was slightly different from that of $P$. chaii (1.98:1). The ratio of OS/ VS was the same, 2.60:1, and the ratio of OS/BL was slightly different from each other (Table 7). Moreover, P. chaii metacercariae were previously detected in the same clam hosts, $M$. veneriformis, collected in Seocheon-gun, Chungcheongnamdo, which is located nearby in the surveyed area of this study, Taean-gun [10]. However, the remaining 2 types of metacercariae (Type B and C) were morphologically different from $P$. chaii metacercariae [10]. The metacercariae Type B was apparently similar to $P$. duboisi metacercariae; however, their body size was much smaller than that of $P$. duboisi. Further studies with molecular analysis are needed in the future to clarify the taxonomic positions of Parvatrema spp. in Korea.

\section{ACKNOWLEDGMENTS}

This study was supported by an anti-communicable diseases control program (no. 2013E54002-00, Studies on obtaining biological resources of human-infecting trematodes and the infection status of larvae in their intermediate hosts) of National Institute of Health (NIH), Korea Centers for Disease Control and Prevention (KCDCP). We thank Jung-A Kim and Hee-Joo Kim (Department of Parasitology and Tropical Medicine, Gyeongsang National University School of Medicine, Jinju, Korea), for their help in the examination of clams.

\section{CONFLICT OF INTEREST}

The authors have no conflicts of interest concerning the work reported in this paper.

\section{REFERENCES}

1. Gibson DI. Class Trematoda Rudolphi, 1808; Subclass Digenea Carus, 1863. In Jones A, Bray RA, Gibson DI eds, Keys to the Trematoda, Vol. 1. London, UK. CABI Publishing and Natural History Museum. 2002, pp 1-3, 15-18.

2. Sohn WM. Fish-borne zoonotic trematode metacercariae in the Republic of Korea. Korean J Parasitol 2009; 47: 103-113.

3. Sohn WM. Invertebrate Fauna of Korea. Vol. 6, No. 1. Trematodes. Incheon, Korea. The National Institute of Biological Resources. 2013, pp 1-125.

4. Yu JR, Chai JY, Lee SH. Parvatrema timondavidi (Digenea: Gymnophallidae) transmitted by a clam, Tapes philippinarum, in Korea. Korean J Parasitol 1993; 31: 7-12.

5. Lee SH, Choi MH, Seo M, Chai JY. Oysters, Crassostrea gigas, as the second intermediate host of Gymnophalloides seoi (Gymnophallidae). Korean J Parasitol 1995; 33: 1-7.

6. Sohn WM, Chai JY, Lee SH. Infection status of Tapes philippinarum, collected from southern coastal areas of Korea with Parvatrema spp. (Digenea: Gymnophallidae) metacercariae. Korean J Parasitol 1996; 34: 273-277 (in Korean).

7. Lee SH, Sohn WM, Hong SJ, Huh S, Seo M, Choi MH, Chai JY. A nationwide survey of naturally produced oysters for infection with Gymnophalloides seoi metacercariae. Korean J Parasitol 1996; 34: 107-112.

8. Sohn WM, Ryang YS, Chai JY, Lee SH. Discovery of Gymnophalloides seoi metacercariae in oysters from islands of the West Sea known as the habitats of palearctic oystercatchers. Korean J Parasitol 1998; 36: 163-169.

9. Kim YG, Yun KS. Trematode larvae in 3 species of bivalves (Corbicula japonica, Sinnovacula constricta and Ruditapes philippinarum). J Fish Pathol 2003; 16: 203-213.

10. Sohn WM, Na BK, Ryang YS, Ching HL, Lee SH. Parvatrema chaii n. sp. (Digenea: Gymnophallidae) from mice experimentally infected with metacercariae collected from surf-clam, Mactra veneriformis. Korean J Parasitol 2007; 45: 115-120.

11. Chai JY, Han ET, Choi D, Seo M, Kim JL, Guk SM, Shin EH, Lee $\mathrm{SH}$. A new gymnophallid trematode from the intestine of mice infected with metacercariae from the razor clam Sinonovacula constricta. J Parasitol 2007; 93: 132-137.

12. Kim YG, Chun SK. Studies on a trematode parasitic in bivalves. IV. On the metacercaria of Himasthla kusasigi Yamaguti, 1939 (Trematoda) found in the clam, Meretrix lusori Roding. Bull Korean Fish Soc 1984; 17: 61-67.

13. Kim YG. Studies on the trematode parasitized on bivalves. V. On metacercaria of echinostomatidae detected from Mactra veneriformis, Cyclina sinensis and Solen strictus. J Fish Pathol 1988; 1: 3137.

14. Chai JY, Han ET, Park YK, Guk SM, Lee SH. Acanthoparyphium tyosenense: the discovery of human infections and identification of its source. J Parasitol 2001; 87: 794-800.

15. Han ET, Chai JY. Mactra veneriformis, an intertidal clam, as a new second intermediate host for Acanthoparyphium marilae (Digenea: 
Echinostomatidae). Korean J Parasitol 2008; 46: 101-104.

16. Han ET, Whang JD, Chai JY. Himasthla alincia (Echinostomatidae): metacercariae in brackish water bivalves and their growth and development in experimental animals. J Parasitol 2009; 95: 1415-1420.

17. Lee SH, Chai JY, Hong ST. Gymnophalloides seoi n. sp. (Digenea: Gymnophallidae), the first report of human infection by a gymnophallid. J Parasitol 1993; 79: 677-680.

18. Lee SH, Chai JY, Lee HJ, Hong ST, Yu JR, Sohn WM, Kho WG, Choi MH, Lim YJ. High prevalence of Gymnophalloides seoi infection in a village on a southwestern island of the Republic of Korea. Am J Trop Med Hyg 1994; 51: 281-285.

19. Chai JY, Lee SH. Food-borne intestinal trematode infections in the Republic of Korea. Parasitol Int 2002; 51: 129-154.

20. Lee SH, Chai JY. A review of Gymnophalloides seoi (Digenea: Gymnophallidae) and human infections in the Republic of Korea. Korean J Parasitol 2001; 39: 85-118.

21. Chai JY, Song TE, Han ET, Guk SM, Park YK, Choi MH, Lee SH. Two endemic foci of heterophyids and other intestinal fluke infections in southern and western coastal areas in Korea. Korean J Parasitol 1998; 36: 155-161.

22. Chai JY, Park JH, Han ET, Shin EH, Kim JL, Hong KS, Rim HJ, Lee SH. A nationwide survey of the prevalence of human Gym- nophalloides seoi infection on western and southern coastal islands in the Republic of Korea. Korean J Parasitol 2001; 39: 2330.

23. Lee YI, Chung OS, Seo M. Recovery of Oswaldotrema nacinovici from whimbrels (Aves) in Korea. Korean J Parasitol 2016; 54: 809-812.

24. Yamaguti S. Studies on the helminth fauna of Japan. Part 25. Trematodes of birds, IV. Jpn J Zool 1939; 8: 131-210.

25. Diaz JI, Cremonte F. Himasthla escamosa n. sp. (Digenea: Echinostomatidae) from the kelp gull, Larus dominicanus (Charadriiformes: Laridae), on the Patagonian coast, Argentina. J Parasitol 2004; 90: 308-314.

26. Yamaguti S. Part I. The Digenetic Trematodes of Vertebrates. In Systema Helminthum, Vol. I. New York, USA. Interscience Publishers. 1958, pp 1-979.

27. Chen HT. Fauna Sinica. Platyhelminthes Trematoda. Digenea (I). Beijing, China. Science Press. 1985, pp 1-697 (in Chinese).

28. Rybakov AV, Lukomskaya OG. On the life cycle of Acanthoparyphium macracanthum sp. n. (Trematoda: Echinostomatidae). Parazitologiya 1988; 22: 224-229 (in Russian).

29. Skrjabin KI. Trematodes of Animals and Man. Essentials of Trematology, Vol. XII. Moscow, Russia. Academy Science USSR. 1956, pp 1-932. 